УДК 373.5.016:811.111(07)

DOI: https://doi.org/10.35619/iiu.v0i9.19

Iryna Perishko

$\mathrm{PhD}$ in Pedagogy, Associate Professor, Associate Professor at Practice of the English Language Department, Rivne State University of the Humanities,

Rivne, Ukraine ORCID: 0000-0002-5232-5945, e-mail: perishko_irina@ukr.net

\title{
ENHANCING STUDENTS' INTERESTS VIA WEB-BASED TOOLS
}

\begin{abstract}
The article focuses on students' interests, it can be found out how to use the Internet to construct interest-based learning for students. It is known that students produce their best work when they are interested in what they are doing. As the paper highlights, knowing students' interests is the first step to enhancing their education. A teacher's task is to continually encourage the exploration of their interests.

The article examines the problem of energizing students with the help of web-based tools. The reasons of video games appealing are mentioned. The video microworlds are still captivating today as enabling users can transfer technology to real world settings. It is specially noted that the Internet is a medium for communication in the world. School progress is often linked to the ability of teachers to tie student interests and desires to school activities. It should be emphasized that the classroom teacher and the student now have numerous possibilities for problem- and project-based learning, telecollaborative and scaffolding experiences.

In the paper special attention is given to web sites on the Internet. In teaching many Web Based instructional sites provide scaffolding prompts in various forms that give a better chance to use knowledge independently. It gives support in research for instruction based on addressing student interest. Learner interest can be important to a student's academic development.
\end{abstract}

Key words: students' interests, interest-based learning, problem- and project-based learning, web-based tools, telecollaboration, scaffolding.

Formulation of the problem. Teachers are always looking for ways to keep children active in the classroom. One successful strategy is to organize motivating experiences around students' interests.

Renzulli and Reis (2008) argues that all cognitive behavior is enhanced based on the person's level of interest in whatever he or she is learning, whether it is basic skills learning or higher levels of conceptualization and creative productivity. Before teachers can tap into these interests, an assessment must be made to get a snapshot of a child's interest.

The aim of the article is to examine the problem of energizing students with the help of web-based tools.

Presenting the main material. Teachers know that students produce their best work when they are interested in what they are doing. The first challenge is to learn about students' individual interests (recognizing that interest assessments are more powerful tools when used in the context of their information such as abilities, personality, and other biographical information), and the next hurdle is to incorporate those interests into opportunities in the classroom. 
Renzulli developed the Interest-A-Lyzer, an instrument designed to help young people identify their interests. Adaptations are available for students from primary ages through adult using questions designed to discover and excite both general and specific areas of interest (see Resources section below).

The following open-ended questions from the Interest-A-Lyzer can be used to begin conversations about general interests at any age:

- "Imagine that a time machine has been invented that will allow famous people

from the past to travel through time. If you could invite some of these people to visit your class, who would you invite?"

- "Imagine that you can spend a week shadowing any person in your community

to investigate a career you might like to have in the future. List the occupations of the people you would select."

While general interests are a good starting point, specific interests and sustained activities outside of school are useful indicators for classroom differentiation.

Two issues are important to recognize as students consider their general and specific interests. First, young people often have a variety of interests, although some students will respond that nothing interests them. Talking openly about the range of possibilities in interest levels, from idle curiosity to intense passion, creates a safe environment for students to explore interests without exposing their lack of prior knowledge. Second, interests change over time. It is useful to check frequently to discover new, emerging interests and trends within the classroom.

Teacher made or researched-based interest inventories (see Resources section below) are readily available for classroom use and can be tallied by the teacher to organize instruction and enrichment opportunities.

\section{Resources}

Several interest inventories are available from Creative Learning Press 860/429-8118

Primary Interest-A-Lyzer - developed for grades K-3 to examine potential interests.

Interest-A-Lyzer - for upper elementary and middle school to assess potential interests through open-ended questions.

The secondary Interest-A-Lyzer - for middle and high school to tap into advanced interest pursuits.

The Primary-Art-Interest-A-Lyzer or Art-Interest-A-Lyzer - offers young students and middle school students a medium for exploring present and potential interest in a variety of artistic mediums.

\section{Software Tools}

Microsoft Classroom Training Tools - which includes templates, clipart, lesson plans. https://www.microsoft.com/en-us/education/school-leaders/teachingand-learning/default.aspx

Data Explorer - a data analysis and graphing software application https://datavizcatalogue.com/methods/sunburst_diagram.html

Kidpix - allows students to create multimedia projects: https://www.learning.com/

\section{Sites for Finding Mentors}

Pitsco's Ask An Expert - http://www.askanexpert.com/ 
Ask.com for Kids - https://ajkids.com/

Teacher Created Resources - https://www.teachercreated.com/urlupdates/3831

Classroom Connect - https://www.teaching.com.au/page/mta-au-classroomconnect

\section{Sites that use Online Reflections}

Problem Based Learning scenarios:

E-mail Privacy Problem - https://www.solarwindsmsp.com/content/emailprivacy-issues

Medical Ethics Problems - https://www.headrushlearning.com/

Annenberg Exhibits Collection - learner.org/exhibits/ theNSRF/

The National Student Research Forum - https://www.facebook.com/

\section{Collaborating by Sharing Data}

The Globe program - https://www.globe.gov/

Knowledge Forum - http://www.knowledgeforum.com/

\section{Accessing Information}

Pattie Student Research Center

https://www.baylor.edu/lib/grc/index.php?id=935277 (This site includes links developed by parents based on teacher-parent collaboration.)

Addressing the range of student interests in any one classroom in daunting. Using technology, in particular the World Wide Web (WWW), to highlight several forms of instruction may be helpful for today's wired, or semi-wired classroom.

Almost forty years ago, Malone (1981) studied the use of Nintendo and why it was so captivating for children. He identified three reasons why video games were appealing:

- the game had a specific goal (the most important factor),

- it had an element of fantasy,

- it had an element of curiosity.

These three areas offered more than television could and "video games the first medium to combine visual dynamism with an active participatory role for the child" (Greenfield, 1994). These microworlds are still captivating today as the field has expanded to include SEGA and hand-held games.

Expanding beyond the video microworlds and enabling users to transfer technology to real world settings, Tim Berners-Lee (2000) invented the WWW as a medium for the world to communicate. "The fundamental principle behind the Web was that once someone somewhere made available a document, database, graphic, sound, video, or screen at some stage in an interactive dialogue, it should be accessible (subject to authorization, of course) by anyone with any type of computer in any country" (p. 37).

The sheer volume of information that is now readily accessible is both terrifying and exciting for educators. The opportunities that Web Based Instruction brings to the classroom enable the expression of the learners' style to be meshed with possibilities of collaboration or independent explorations aided by an on-line mentor. Blending instruction with mentors from around the globe transforms our view of curriculum and enables the teacher to go beyond the static information of the textbook.

Current research and web sites on the Internet are using terms such as constructivist, problem- and project-based learning, telecollaborative and scaffolding 
to define how learning can occur when technology is used as a tool. The classroom teacher and student now have numerous possibilities for authentic learning experiences.

Project-based learning involves students identifying problems (Renzulli \& Reis, 1997) or goals of personal or group interest and generating activities and products to solve the problems or meet the goals (Blumenfeld et. al. 1991). Students interested in this type of learning are those who enjoy collaboration, questioning, and defining the abstract and are motivated to search in-depth and across disciplines while being held accountable for project development and communication of findings. Software that provides charting capabilities, (e.g. Microsoft Classroom Training Tools and Data Explorer) would be helpful for this type of learning. If the project is telecollaborative, a shared database that provides a forum for discussion and reflection of logged notes (e.g. The Globe Program or Knowledge Forum) would be helpful.

Scaffolds are external aids (e.g. Kidpix - "Small Kids Mode") that provide the support in both cognitive and social realms to the learner who is new to the task or knowledge domain (Kozma \& Schank, 1998, p. 16). As students utilize the skills outside the classroom, supports can be gradually removed as the skills become part of the learner's repertoire. Many Web Based instructional sites provide these types of scaffolding prompts in the form of concept maps, case-based libraries and online glossaries. Online notebooks are also used in sites like E-mail Privacy Problem, Medical Ethics or The National Student Research Center to capture a diary of reflections or research written by students.

Scaffolds are meant to allow students to manage tasks that are more challenging than those they are able to handle alone (Vygotskyi, 1978). Many highability students and students who prefer to learn independently will be able to search deeper and wider more quickly than their same aged peers as they bypass lower level supports and utilize scaffolds when necessary in the discovery process.

Conclusions and prospects for further research. Many current websites address collaboration in the state, national and global arena. In order for these collaborations to be successful the teacher still needs to be the visionary to circumvent situations that may result in loss of student motivation or would fail due to the lack of specific learning skills. "Teachers must first determine what a child needs to learn and then provide the tools for the child to achieve that objective. Do not underestimate the importance of directed instruction to develop specific skills in children and assist them to develop fluency in using those skills" (Behrmann et. al. 2012, p. 70).

The WWW was developed with a "vision that ... about anything can be connected to anything" (Berners-Lee, 2000, p.1). For our children to keep active, we need to use the WWW to encourage interest-based learning that challenges them to use their imagination and creativity and figure out just how everything does connect to everything.

Thus, helping students identify and pursue their interests can enhance their social and emotional adjustment. And even if they admit to having no interests, a teacher's task is to continually encourage the exploration of interests in hopes that someday there may be something that sparks inquisitiveness and supports their finding a place in this world. 


\title{
REFERENCES:
}

Renzulli, J., Reis, S. (2008). Enriching the curriculum for all students (2nd ed.). Thousand Oaks, CA: Corwing Press, $177 \mathrm{p}$.

Malone, T. W. (1981). Video games as microworlds. In E.F. Provenzo, JR, Video Kids (pp. 39, 43). Cambridge, Massachusetts: Harvard University Press.

Greenfield, P.M. (1994). Video games as cultural artifacts. Journal of Applied Developmental Psychology, 15(1), pp. 3-12.

Berners-Lee, T. (2000). Weaving the web. New York: HarperCollins Publishers.

Renzulli, J., Reis, S. (1997). The Schoolwide Enrichment Model: A how-to guide for educational excellence (2nd ed.). Mansfield, CT: Creative Learning Press.

Blumenfeld, P., Soloway, E., Marx, R., Krajcik, J., Guzdial, M., \& Palincsar, A. (1991). Motivating Project-Based Learning: Sustaining the Doing, Supporting the Learning. Educational Psychologist, 26(3-4), pp. 369-398.

Kozma, R., Schank, P. (1998). Connecting with the 21st century: Technology support of educational reform. In C. Dede (Ed.), ASCD yearbook 1998 Learning with technology (pp. 3-29). Alexandria, VA: ASCD.

Vygotsky, L. (1978). Mind in society: Development of Higher Psychological Processes [pdf]

Harvard University Press. - URL: http://ouleft.org/wp-content/uploads/VygotskyMind-in-Society.pdf [Accessed 05.02.2019].

Behrmann M., Chung, Y., Bannan B. \& Thorp. Y. (2012). Perspectives of high tech augmentative and alternative communication users with cerebral palsy at the postsecondary level. Perspectives on Augmentative and Alternative Communication, 21 (2), pp. 30-71.

\section{ПІДВИЩЕННЯ ІНТЕРЕСУ УЧНІВ ДО НАВЧАННЯ ЗА ДОПОМОГОЮ ЗАСОБІВ ВСЕСВІТНЬОЇ МЕРЕЖІ}

\author{
Перішко Ірина \\ кандидат педагогічних наук, доцент, \\ доцент кафедри практики англійської мови \\ Рівненського державного гуманітарного університету, \\ м. Рівне, Україна \\ ORCID: 0000-0002-5232-5945, \\ e-mail: perishko_irina@ukr.net
}

\footnotetext{
Анотація. Стаття присвячена зростанню інтересу учнів до навчання, 3'ясовуються способи використання Інтернету в навчальному процесі. Відомо, що учні виконують свою роботу найкраще тоді, коли вони зацікавлені в тому, що роблять. Як наголошується у статті, обізнаність 3 інтересами учнів є першим кроком до покращення їхньої освіти. Успіхи у навчанні часто пов'язані зі здатністю вчителів прив'язувати інтереси та бажання дітей до шкільної діяльності. Завдання вчителя полягає в тому, щоб постійно заохочувати їх зацікавленість.

У статті розглядається проблема активізації учнів за допомогою веб-засобів, наводяться причини привабливості відеоігор. Сьогодні мікросвіт відео $\epsilon$ захопливим, оскільки дає можливість користувачам переносити технології та моделювати процес у реальних ситуаціях. Успіхи в навчанні часто пов'язані зі здатністю вчителів прив'язувати інтереси та бажання учнів до шкільної діяльності. Відзначається, що Інтернет $\epsilon$ засобом комунікації у світі, і вчителі та учні в класі тепер мають численні можливості для проблемного і проектного навчання, телеколаборації і скаффолдингу.
} 
У роботі особлива увага приділяється веб-сайтам в Інтернеті, які допомагають у навчанні, яке базується на врахуванні інтересів учня. Багато веб-навчальних сайтів надають різні форми скаффолдингу, що забезпечує кращу можливість використовувати знання самостійно. Термін «скаффолдинг» використовується викладачами для опису засобів, які вчитель надає учням для того, щоб допомогти їм бути успішними під час виконання складних завдань. Веб-застосунки надають підтримку та можливість дитині розв'язати проблему, виконати завдання або досягнути цілей, що спрямовані на розвиток інтересу до навчання. Ця підтримка може «демонтуватися», як тільки учень справляється 3 завданням самостійно. Процес навчання стає процесом дослідження й інтерес учня $є$ важливим для його академічного розвитку. Допомога учням у виявленні інтересів може підвищити їх соціальну та емоційну адаптацію і навіть, якщо вони визнають, що не мають жодних інтересів, завдання вчителя полягає в тому, щоб постійно заохочувати дослідження зацікавленості, сподіваючись, що одного дня може виникнути щось, що викликає допитливість і це допоможе знайти їм себе у майбутньому.

Ключові слова: інтереси учнів, навчання на основі інтересів, проблемне та проектне навчання, веб-інструменти, телеколаборація, скаффолдинг.

Стаття надійшла до редакиії 07.02.2019 р. 